\section{Bartonella henselae DNA in Seronegative Patients with Cat-Scratch Disease}

\section{Masashi Yanagihara, Hidehiro Tsuneoka, Ayano Tanimoto, Ken-ichiro Otsuyama, Jun Nishikawa, Tomohiro Matsui, Junzo Nojima, Kiyoshi Ichihara}

Author affiliation: Yamaguchi University, Ube, Japan

DOI: https://doi.org/10.3201/eid2405.152033

We used real-time PCR to detect Bartonella henselae DNA in $7.9 \%(5 / 63)$ of blood specimens from seronegative patients in Japan suspected of having cat-scratch disease. The combined use of serologic tests and realtime PCR to analyze blood specimens is recommended for the prompt, noninvasive laboratory diagnosis of catscratch disease.

$\mathrm{C}$ at-scratch disease (CSD) is a worldwide zoonosis caused by Bartonella henselae (1). Its clinical manifestations vary from typical CSD with regional lymphadenopathy to atypical or systemic CSD, including prolonged fever without lymphadenopathy. Because isolation of $B$. henselae by culture is difficult (2), detection of $B$. henselae DNA in lymph nodes by PCR and serologic testing using indirect fluorescence antibody (IFA) assay is widely used for laboratory diagnosis of CSD (2-4). Isolation of $B$. henselae DNA from blood specimens of immunocompetent CSD patients has been sporadically described, suggesting that it might be useful, especially for cases in which lymphadenectomy or biopsy is not feasible or serologic results are equivocal (5-9). However, the usefulness of serologic testing, coupled with detection of $B$. henselae DNA from blood specimens, is not well described. We report the clinical utility of the combined use of IFA and real-time PCR to analyze blood specimens for noninvasive screening of CSD.

During April 2009-May 2014, eighty immunocompetent patients ( 73 children, 7 adults) in Japan who were suspected of having CSD because of fever with or without lymphadenopathy, and a history of contact with cats or dogs were referred to us for serologic and molecular diagnosis of CSD. We conducted serologic testing using IFA $(3,4)$; diagnosis was based on elevated titers of $\operatorname{IgM}(\geq 20)$ or $\operatorname{IgG}$ $(\geq 256)$. The sensitivity and specificity of our IFA were $69 \%$ and $100 \%$, respectively (4). Real-time PCR (rPCR) detected specific $B$. henselae virB4 DNA from blood specimens as reported previously (9). In brief, we extracted DNA from peripheral blood using a QIAamp DNA Mini Kit
(QIAGEN, Hilden, Germany). The $20-\mu \mathrm{L}$ PCR mixture contained $10 \mu \mathrm{L} 2 \times$ LightCycler 480 Probes Master Mix (Roche Diagnostics, Mannheim, Germany), $0.4 \mu \mathrm{mol} / \mathrm{L}$ of each primer (forward: 5'-AGCGAAGAAAACACAATCTGAA-3'; reverse: 5'-TCCATAGCTTTCCAATCCTTCT-3'), $0.1 \mu \mathrm{mol} / \mathrm{L}$ Universal ProbeLibrary probe no. 135 (Roche Diagnostics), and $5 \mu \mathrm{L}$ DNA. We conducted the reaction using a LightCycler 480 instrument (Roche Diagnostics) under the following conditions: denaturation at $95^{\circ} \mathrm{C}$ for $5 \mathrm{~min}$ and 45 cycles of $95^{\circ} \mathrm{C}$ for $10 \mathrm{~s}, 60^{\circ} \mathrm{C}$ for $30 \mathrm{~s}$, and $72^{\circ} \mathrm{C}$ for $1 \mathrm{~s}$. We determined crossing point $(\mathrm{Cp})$ values using the second derivative maximum method and analyzed all samples in triplicate.

This assay detected all 56 specimens evaluated as $B$. henselae (10), but other Bartonella species were not identified (9). The lower quantitative detection limit of this assay was 4.6 DNA copies/reaction using serial dilutions of plasmid DNA.

Of the 80 patients with suspected CSD, 17 (21.3\%) were serologically positive for $B$. henselae by IFA. $B$. henselae DNA was amplified from the peripheral blood of $11(13.8 \%)$ patients by rPCR. Six patients were positive by both IFA and rPCR. CSD was diagnosed in $22(27.5 \%)$ of the 80 patients (Table). Cp values of the IFA-positive and -negative patients did not differ.

Despite the high specificity, IFA lacks sensitivity (4). This study showed that CSD detection sensitivity increased from $21.3 \%(17 / 80)$ using IFA alone to $27.5 \%(22 / 80)$ with combined use of IFA and rPCR on blood specimens. We attribute this increase to the detection of $B$. henselae DNA in 5 patients with seronegative results. Four patients (nos. 6, 8, 10, and 17) exhibited typical CSD with fever and regional lymphadenopathy, and 1 (no. 3) had fever of unknown origin without lymphadenopathy (Table). After laboratory diagnosis, these patients were treated with macrolides to reduce fever. These observations suggested that these patients were in the initial stages of the illness (before a significant rise of antibodies to $B$. henselae) or that the patients' immune responses were insufficient to produce antibodies to $B$. henselae (5).

We detected $B$. henselae DNA in blood specimens of $35.3 \%(6 / 17)$ of the seropositive patients in our study, whereas previous studies detected DNA in 19.2\% (5/26) of blood specimens from seropositive patients (5) and $16.7 \%$ $(3 / 18)$ of serum specimens from patients proven to have CSD (6). rPCR using blood specimens was not sensitive enough when used alone because $B$. henselae DNA is not present in the bloodstream in all patients. The time points at which $B$. henselae DNA can be detected in blood specimens are still unknown. A previous report described this time point as 3 weeks after onset of lymphadenopathy (7), whereas another study considered it to be 3-4 months after infection (8). Most specimens used in our study were 
Table. Description of patients with cat-scratch disease and results of IFA and rPCR of blood specimens, Japan, April 2009-May 2014*

\begin{tabular}{|c|c|c|c|c|c|c|c|c|}
\hline \multirow[b]{2}{*}{ Patient no. } & \multirow{2}{*}{$\begin{array}{c}\text { Patient age, } \\
\text { y/sex }\end{array}$} & \multirow[b]{2}{*}{ Fever } & \multirow{2}{*}{$\begin{array}{c}\text { Regional } \\
\text { Iymphadenopathy }\end{array}$} & \multirow{2}{*}{$\begin{array}{c}\text { History of contact } \\
\text { with animal }\end{array}$} & \multicolumn{2}{|c|}{ IFA titer } & \multirow{2}{*}{$\begin{array}{l}\text { Cp of } r P C R, \\
\text { mean } \pm S D\end{array}$} & \multirow[b]{2}{*}{ Complication } \\
\hline & & & & & $\lg M$ & $\lg G$ & & \\
\hline 1 & $15 / \mathrm{M}$ & + & + & Cat, dog & 40 & 256 & NA & \\
\hline 2 & $4 / F$ & + & - & Cat & 20 & 512 & $36.82 \pm 0.57$ & FUO \\
\hline 3 & $6 / F$ & + & - & Dog & $<10$ & 64 & $33.93 \pm 0.39$ & FUO \\
\hline 4 & $13 / \mathrm{M}$ & + & + & Cat & $<10$ & 256 & $35.98 \pm 0.69$ & \\
\hline 5 & $14 / F$ & + & + & Cat, dog & $<10$ & 256 & $34.29 \pm 0.43$ & \\
\hline 6 & $8 / \mathrm{M}$ & + & + & Dog & $<10$ & $<64$ & $35.35 \pm 0.33$ & \\
\hline 7 & 10/M & + & + & Cat & 20 & 256 & NA & \\
\hline 8 & $8 / F$ & + & + & Dog & $<10$ & $<64$ & $37.18 \pm 0.36$ & \\
\hline 9 & $10 / \mathrm{M}$ & + & + & Cat & 20 & 256 & NA & \\
\hline 10 & $7 / F$ & + & + & Cat & 10 & $<64$ & $35.64 \pm 0.27$ & \\
\hline 11 & $2 / \mathrm{M}$ & + & + & Cat & 40 & 256 & NA & \\
\hline 12 & $15 / \mathrm{M}$ & + & - & Cat, dog & $>80$ & 512 & NA & Neuroretinitis \\
\hline 13 & $6 / F$ & + & + & Cat & $<10$ & 256 & $37.29 \pm 0.15$ & \\
\hline 14 & $10 / \mathrm{M}$ & + & + & Cat & $<10$ & 256 & NA & \\
\hline 15 & $12 / F$ & + & + & Cat, dog & $<10$ & 512 & $33.55 \pm 0.33$ & \\
\hline 16 & 13/M & + & - & Cat & $<10$ & 512 & NA & FUO \\
\hline 17 & $9 / F$ & + & + & Cat & $<10$ & $<64$ & $34.84 \pm 0.47$ & \\
\hline 18 & $4 / \mathrm{M}$ & + & + & Cat & 20 & 512 & NA & \\
\hline 19 & $14 / F$ & + & - & Dog, rabbit & 80 & 512 & NA & Neuroretinitis \\
\hline 20 & $56 / F$ & + & - & Cat & $<10$ & 256 & NA & Neuroretinitis \\
\hline 21 & $35 / F$ & + & + & Cat & 40 & 1,024 & $37.19 \pm 0.59$ & \\
\hline 22 & $7 / \mathrm{M}$ & + & + & Cat, dog & $<10$ & 512 & NA & \\
\hline
\end{tabular}

*Blank cells indicate no complications. Cp, crossing point value; FUO, fever of unknown origin; IFA, indirect fluorescent antibody test; NA, no amplification by rPCR; rPCR, real-time PCR; +, positive; -, negative.

collected within 3 weeks after symptom onset. Regardless of the days after onset, rPCR testing of blood specimens should be performed actively because patients may experience bacteremia or the shedding of bacterial breakdown products into the bloodstream.

In conclusion, our study showed that rPCR testing of blood specimens can detect $B$. henselae DNA in patients with seronegative results. The combined use of IFA and rPCR on blood specimens is useful for the noninvasive screening of CSD.

This work was supported by Japan Society for the Promotion of Science KAKENHI (Grant-in-Aid for Young Scientists [B]) grant no. 24790554.

\section{About the Author}

Dr. Yanagihara is an assistant professor in the Department of Laboratory Sciences, Faculty of Health Sciences, Yamaguchi University Graduate School of Medicine. His primary research interest is $B$. henselae infection.

\section{References}

1. Anderson BE, Neuman MA. Bartonella spp. as emerging human pathogens. Clin Microbiol Rev. 1997;10:203-19.

2. La Scola B, Raoult D. Culture of Bartonella quintana and Bartonella henselae from human samples: a 5-year experience (1993 to 1998). J Clin Microbiol. 1999;37:1899-905.

3. Regnery RL, Olson JG, Perkins BA, Bibb W. Serological response to "Rochalimaea henselae" antigen in suspected cat-scratch disease. Lancet. 1992;339:1443-5. http://dx.doi.org/10.1016/ 0140-6736(92)92032-B

4. Tsuneoka H, Tsukahara M. Analysis of data in 30 patients with cat scratch disease without lymphadenopathy. J Infect Chemother. 2006;12:224-6. http://dx.doi.org/10.1007/s10156-006-0454-Y

5. Tsukahara M, Iino H, Ishida $C$, Murakami K, Tsuneoka $H$, Uchida M. Bartonella henselae bacteraemia in patients with cat scratch disease. Eur J Pediatr. 2001;160:316. http://dx.doi.org/ 10.1007/PL00008437

6. Vermeulen MJ, Diederen BM, Verbakel H, Peeters MF. Low sensitivity of Bartonella henselae PCR in serum samples of patients with cat-scratch disease lymphadenitis. J Med Microbiol. 2008;57:1049-50. http://dx.doi.org/10.1099/jmm.0.2008/001024-0

7. Maruyama S, Kabeya H, Nogami S, Sakai H, Suzuki J, Suzuki H, et al. Three cases of cat scratch disease diagnosed by indirect immunofluorescence antibody assay and/or polymerase chain reaction of 16S rRNA gene of Bartonella henselae. J Vet Med Sci. 2000;62:1321-4. http://dx.doi.org/10.1292/jvms.62.1321

8. Arvand M, Schäd SG. Isolation of Bartonella henselae DNA from the peripheral blood of a patient with cat scratch disease up to 4 months after the cat scratch injury. J Clin Microbiol. 2006;44:2288-90. http://dx.doi.org/10.1128/JCM.00239-06

9. Kimura S, Hasegawa S, Yanagihara M, Inoue H, Matsushige T, Tsuneoka H, et al. Cat-scratch disease with severe pleuritis in a 6-year-old girl. Pediatr Int. 2015;57:501-3. http://dx.doi.org/ 10.1111/ped.12680

10. Yanagihara M, Tsuneoka H, Sugasaki M, Nojima J, Ichihara K. Multispacer typing of Bartonella henselae isolates from humans and cats, Japan. Emerg Infect Dis. 2010;16:1983-5. http://dx.doi.org/10.3201/eid1612.100962

Address for correspondence: Masashi Yanagihara, Yamaguchi University Graduate School of Medicine-Department of Laboratory Sciences, Faculty of Health Sciences, 1-1-1 Minami-kogushi, Ube, Yamaguchi 755-8505, Japan, email: m-yanagi@yamaguchi-u.ac.jp 